eCAM 2006;3(4)395-396

doi:10.1093/ecam/nel086

\title{
Editorial
}

\section{eCAM: On To Year 4}

\section{Edwin L. Cooper}

\author{
Laboratory of Comparative Neuroimmunology, Department of Neurobiology, David Geffen School of Medicine \\ at UCLA, University of California at Los Angeles, Los Angeles, CA 90095-1763, USA
}

With this issue of volume 3, we come to an end and a beginning. We are at a momentous threshold, one that begins with a glimmer of recognition that our efforts have been on target. How do I know this? Let me count the ways! First, there was at the end of June 2006, a palpable increase in the numbers of PDF downloads. In fact the 100000 or so for volume 1 in 2004 was superceded impressively by 150000 for volume 2 in 2005 to a remarkable 150000 for one-half of volume 3, 2006. Let us see what happens at this year's end as we enthusiastically open the covers for volume 4 . What is waiting in the papers? With the end of volume 3 will the level rise to 200000 ? And if so it would be of interest to know if comparable numbers exist for CAM journals first and foremost and for other journals that publish work that encompasses a variety of disciplines.

Almost 4 years ago, when $e C A M$ was just an embryo, we were forming our editorial concept for the journal. At that time we envisioned a place where scientists could discuss with philosophers and historians as well as the practitioners of all the modalities of CAM. Often when we send a more philosophically or historically oriented paper to reviewers, they question its place in $e C A M$. Just as an idea without evidence can lead one astray so, too, can evidence without a continuing discussion of the ideas that initiated its discovery. In recent issues, we have published articles that seek a scientific evidence base for ' $\mathrm{ki}$ ' (1-3) and now in this issue we open up the concept more philosophically with a commentary, 'What is Qi?'(4).

In these first three volumes, has our eclectic approach enabled us to carve out a niche in CAM? I think so and I am optimistic that an even greater impact is ahead. So what are our new directions for the next volume? Around us, we can see the growing need for approaches to the pressing problems

For reprints and all correspondence: Edwin L. Cooper, Laboratory of Comparative Neuroimmunology, Department of Neurobiology, David Geffen School of Medicine at UCLA, University of California at Los Angeles, Los Angeles, CA 90095-1763, USA. Tel: +1-310-825-9567; Fax: +1-310825-2224; E-mail: ecam@mednet.ucla.edu created by older populations in industrialized countries. In other parts of the world, we see the need for cures of infectious diseases that are shortening the life spans of huge populations. And we all share the threat of pandemics about which it is important to remember that the solutions during the SARS epidemic were sought and found within traditional Chinese medicine. Increasingly, the world is turning to CAM (including traditional) modalities to both ameliorate and prevent these extreme conditions that are the source of suffering.

As inaugurated in the first editorial of this volume, our recent efforts to be more inclusive of clinical work have been rewarded by a beginning flow of clinical papers. To aid the process, Writer's Workshops have been successfully convened on both sides of the Pacific and can serve as a model for others (5-7). In fact, another is scheduled for Pune, India, November 2006 (8). While we actively search for stronger and more competitive clinical works, we will encourage reviews that take us far off into the future of science by exploring new areas such as nanosystems and their applicability (9). We will continue to rely on the applicability and relevance of animal models and the efficacy and less controversial in vitro models. We hope that interpreters and liaison makers who will be able to extend the accrued technology and apply it to the human condition take up these in vitro models. These data will engender even more ideas and questions and again data in the endless process of scientific inquiry.

With the increasing number of readers, we have also experienced an encouraging rise in submissions. How has this changed $e C A M$ ? Certainly, we are faced with the need to reject more of the manuscripts that arrive at our door. While our assessment of original research papers and clinical work must by necessity become more and more rigorous, we strive to keep an open mind to commentaries and hypotheses. In the process of organizing an issue, we often use the word 'round' to describe an article or combination of articles. Is the issue 'round' enough? Does it offer food for thought as well as hard scientific evidence? Since many important discoveries began with a question, we hope that you come to $e C A M$ searching 
not only for answers but also for questions that might lead you on a new and exciting path.

\section{References}

1. Ohnishi ST, Ohnishi T, Nishino K, Tsurusaki Y, Yamaguchi M. Growth inhibition of cultured human liver carcinoma cells by Ki-energy (life-energy): scientific evidence for Ki-effects on cancer cells. Evid Based Complement Alternat Med 2005;2:387-93.

2. Ohnishi ST, Ohnishi T. The Nishino breathing method and Ki-energy (life-energy): a challenge to traditional scientific thinking. Evid Based Complement Alternat Med 2006;3:191-200.

3. Ohnishi ST, Ohnishi T, Nishino K. Ki-energy (life-energy) protects isolated rat liver mitochondria from oxidative injury. Evid Based Complement Alternat Med 2006;3:475-82.

4. Flowers J. What is Qi? Evid Based Complement Alternat Med (in press).
5. Feig SA, Speight N, Hynote E, Magaziner A. Summary of the American college for advancement in medicine November 2004 conference on emerging concepts in immunology. Evid Based Complement Alternat Med 2005;2:121-4.

6. Feig SA, Hynote E, Speight N, Magaziner A, Miranda RA, Schachter MB. Summary of the American college for advancement in medicine May 2005 conference: menopause, andropause: power in transition. Evid Based Complement Alternat Med 2005;2:413-9.

7. Feig SA, Biddle J, Hynote E, Speight N, Bock K, Magaziner A, et al. Summary of the American college for advancement in medicine November 2005 conference on scientific integrative medicine: advancing health horizons. Evid Based Complement Alternat Med 2006;3:385-91.

8. Hankey A, Patwardhan B. Second World Ayurveda Congress. Evid Based Complement Alternat Med 2006:3:547-48.

9. Ventura C. CAM and cell fate targeting: molecular and energetic insights into cell growth and differentiation. Evid Based Complement Alternat Med 2005;2:277-83. 


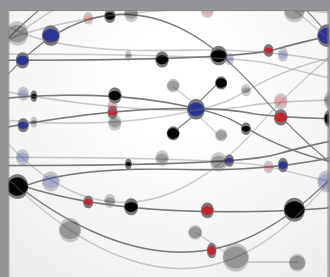

The Scientific World Journal
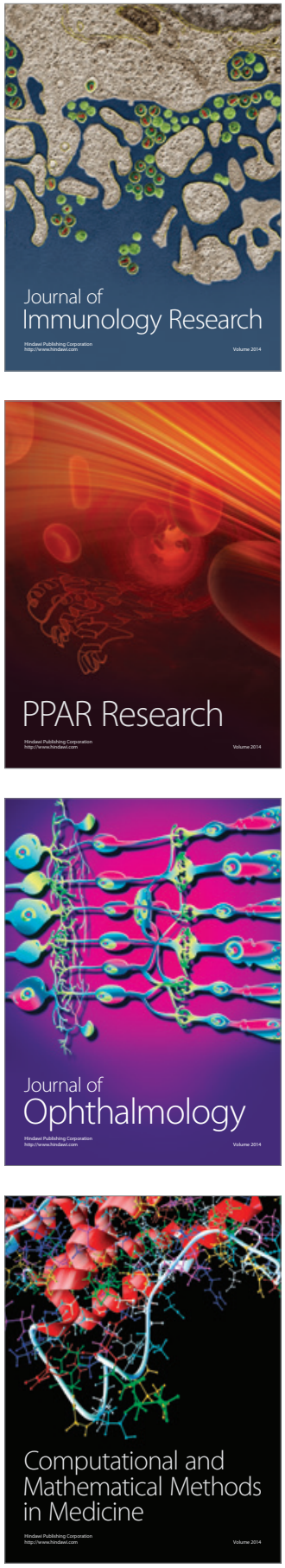

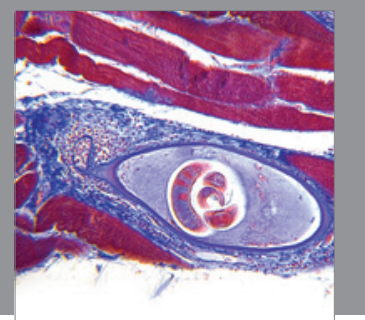

Gastroenterology

Research and Practice
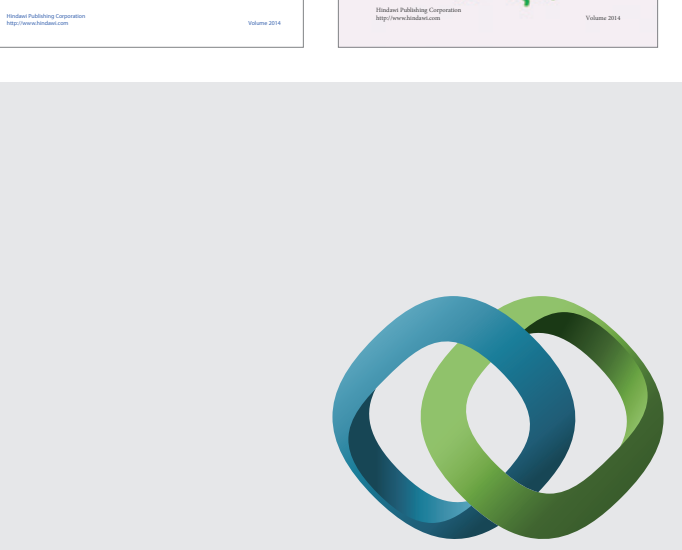

\section{Hindawi}

Submit your manuscripts at

http://www.hindawi.com
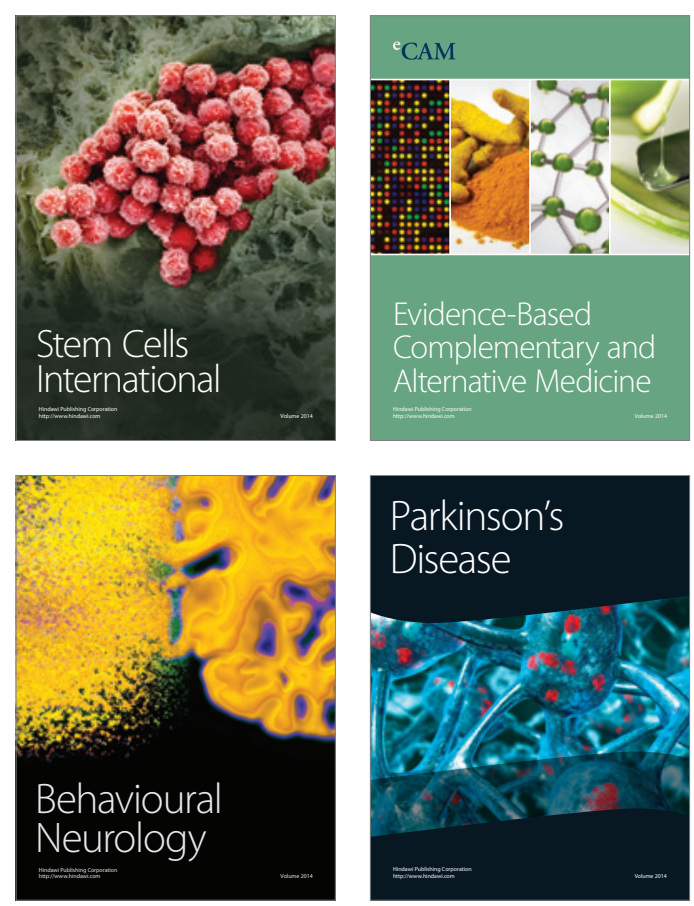

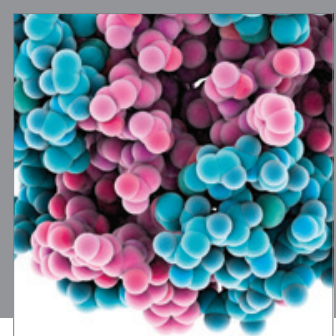

Journal of
Diabetes Research

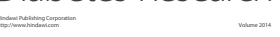

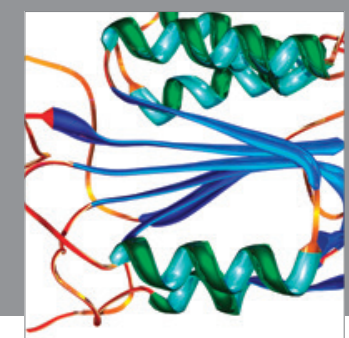

Disease Markers
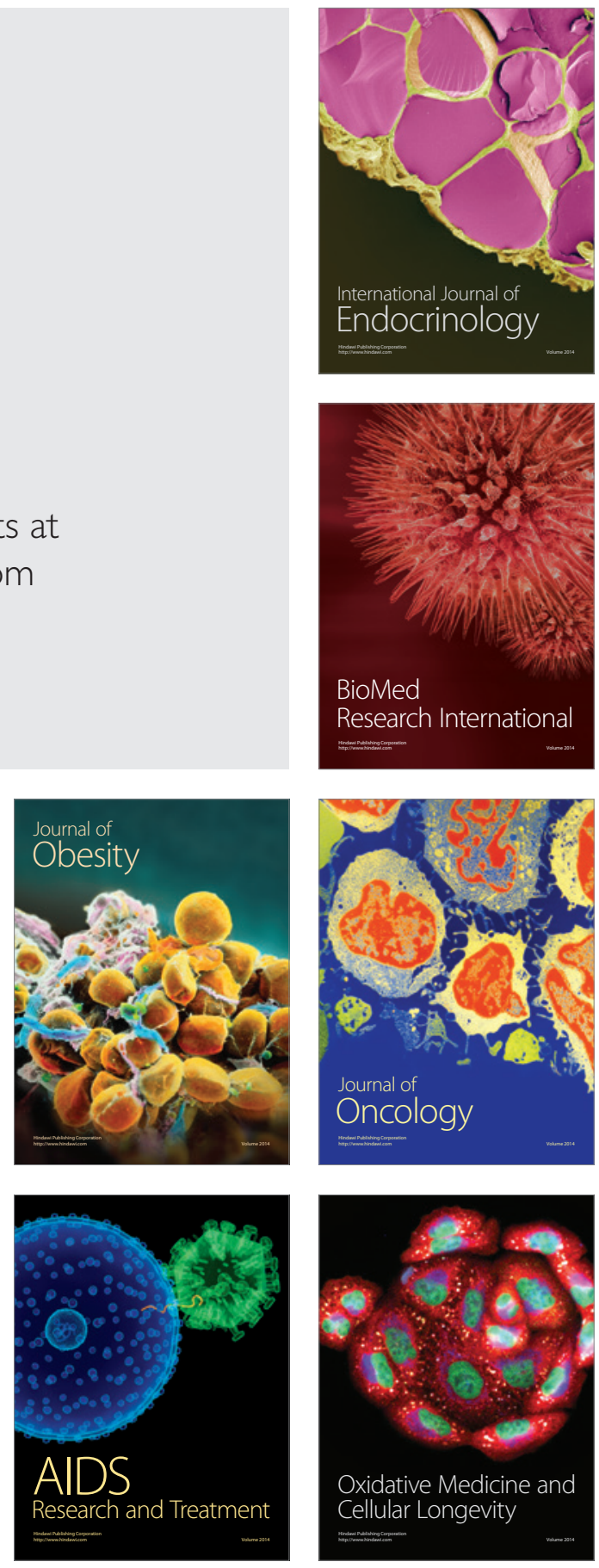